\title{
熱サイクルにともなう熱伝導グリースのポンプアウト現象に関する可視化実験
}

\author{
小西 祐一郎 ${ }^{* 1}$, 堀内 敬介*1, 西原 淳夫*1
}

\section{Visualization experiment on pump-out phenomena of thermal grease under thermal cycling}

\author{
Yuichiro KONISHI ${ }^{* 1}$, Keisuke HORIUCHI ${ }^{* 1}$ and Atsuo NISHIHARA ${ }^{* 1}$ \\ ${ }^{* 1}$ Hitachi, Ltd. Research \& Development Group \\ 832-2 Horiguchi, Hitachinaka-shi, Ibaraki 312-0034, Japan
}

Received: 30 May 2016; Revised: 31 August 2016; Accepted: 30 November 2016

\begin{abstract}
In order to reduce thermal resistance of power module system, Thermal Interface Materials (TIMs) have been used at the interface between baseplate of power module and heat sink. TIMs have an important role to reduce thermal resistances due to solid surfaces with roughness or waviness. Thermal grease is a primary candidate to fill the gap between them. The grease can be pumped out of the gap during thermal cycling while the grease has the advantages of reduced cost compared to the other TIMs and TIM's thickness. New reliability test of the grease is required for thermal management as the pump-out phenomena cause an increase of the thermal contact resistances. This study shows a visualization test method to evaluate pump-out phenomena of the grease during thermal cycling. A bimetal plate consisting of copper and invar is used to simulate thermal deformation of baseplate in power module. The grease is filled between the bimetal plate and $\mathrm{Al}$ thick plate, and then thermal cycling test is conducted. A $25 \mathrm{MHz}$ ultrasonic imaging is used to visualize the grease layer. The ultrasonic images show a sequence of the grease behavior after the thermal cycling. The ultrasonic imaging results indicate that voids occur in non-curing grease under repeated pressure while cracks are detected in curing grease. It is also found that the curing grease layer applied in power devices can be designed by the evaluation of initial thermal contact resistances at the interface. Sensitivity analysis of correlated factors shows pump-out phenomena are strongly affected by curing of grease.
\end{abstract}

Key words : Thermal interface material, Themal grease, Thermal cycling, Pump-out, Ultrasonic imaging

\section{1. 緒言}

近年，パワーエレクトロニクス機器の小型化に伴い，パワーモジュールの高出力密度化が求められている. パ ワーモジュールの高出力密度化を推進するためには，発熱の大きいパワーモジュールの放熱性能向上が必要であ る. パワーモジュールが発する熱は，パワーモジュールに取り付けられた熱伝達性能の高いヒートシンクによっ て筐体外部へ放熱される. 図 1 にパワーモジュールの内部構造と放熱経路の概略図を示す（Lutz et al., 2011）。通 電した素子の発熱は，DCB（Direct Copper Bonding）基板，パワーモジュールの底板であるベースプレート，ヒー

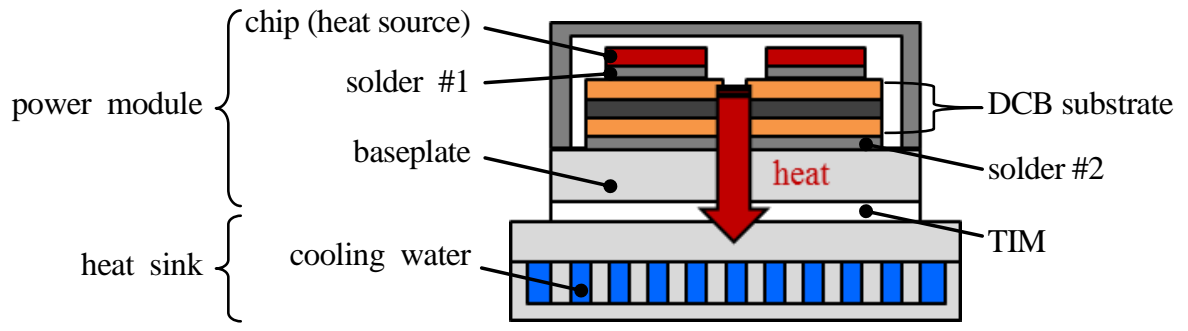

Fig. 1 A typical thermal path from power module to heat sink.

\footnotetext{
No.16-00243 [DOI: 10.1299/transjsme.16-00243], J-STAGE Advance Publication date : 13 December, 2016

*1 正員，(株)日立製作所 研究開発グループ（†312-0034 茨城県ひたちなか市堀口 832-2)

E-mail of corresponding author: yuichiro.konishi.rv@hitachi.com
} 
Table 1 Brief validation of grease pump-out before this study.

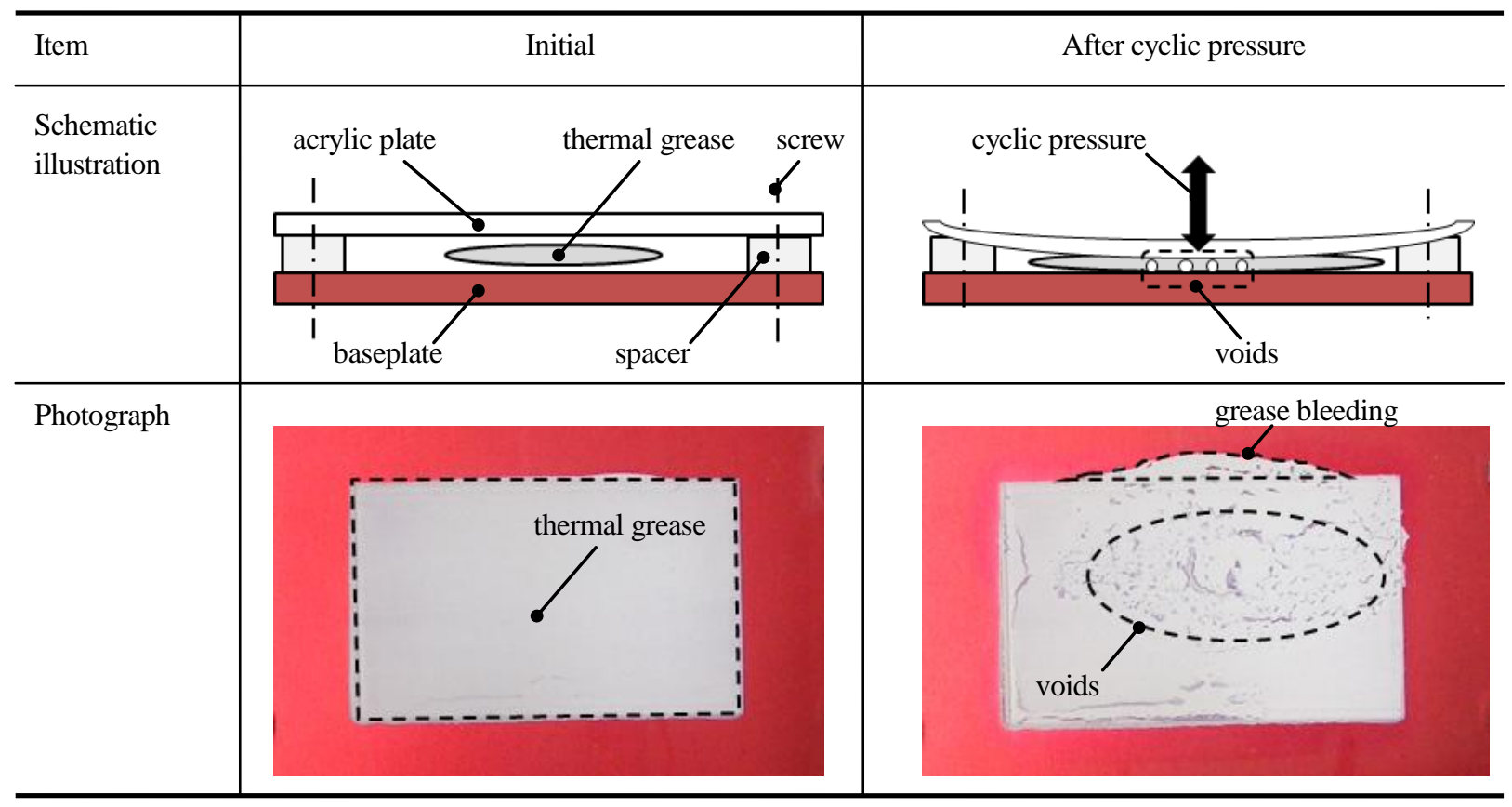

トシンクの順に熱伝導によって伝わる. しかし， ベースプレートとヒートシンクとの間（以下，接続部）には， 接触面の粗さやうねりに起因する隙間が生じる。この隙間に空気が入った状態では, 空気の熱伝導率がヒートシ ンク向け材料であるアルミの約 $1 / 10000$ であることから，空気層を含む接続部の熱抵抗（接触熱抵抗）が大きく なってしまう。そこで，接触熱抵抗を低減するために熱伝導材（Thermal Interface Material, TIM）が広く利用され ており，代表的な熱伝導材に熱伝導グリースが挙げられる．熱伝導グリースは， ベースとなる油と熱伝導率の高 い粒子（フィラー）で構成されるペースト材であり，一般的に $1 \sim 5 \mathrm{~W} /(\mathrm{m} \cdot \mathrm{K})$ 程度の熱伝導率を有する. 一方, 熱 伝導グリースに関する放熱性低下要因の一つにポンプアウト現象が挙げられる．ポンプアウト現象とは，接続部 に充填されたグリースがパワーモジュールの熱変形によって外へ流出した際に，グリース内部にボイド（空隙） が発生するものであり, 熱抵抗の増加を招く。ここで, グリースポンプアウトについて事前検討した結果を表 1 に示す．アクリルプレートとベースプレートとの間に充填されたグリースは，プレートとベースプレートとの間 隔が繰り返し変わることによって，外側へ押し出される．グリースが押し出された結果，空気が中央部に混入す ることがわかる.これまでに, CPU（Central Processing Unit）冷却に関しては，接続部における構成部品の凹凸形 状がグリースの放熱性能に及ぼす影響（Chiu et al., 2000）や，CPU 冷却を想定した装置を用いて現象を再現する 手法 (Chiu et al., 2001; Ramaswamy et al., 2004; Linderman et al., 2007）が検討されている. パワーモジュールについ ては，繰り返し反り変形を機械的負荷によって再現した先行研究（藤本，上貝，2010）があるが，現象発生のメ カニズムの解明にまで至っていない.

そこで本報では，グリースポンプアウト現象の試験方法の確立，ならびに現象発生のメカニズムの解明につな げることを目的として，パワーモジュールの熱変形を模擬した装置で現象を再現し，非破壊評価した結果につい て述べる.

\section{2. グリースのポンプアウト現象の可視化実験方法}

\section{$2 \cdot 1$ ポンプアウト現象に対する影響因子の検討}

グリースのポンプアウトの発生要因を分析するために影響因子を検討した。 パワーモジュールは, ハイブリッ ド電気自動車や電気鉄道車両などに搭載されるインバータの一部品であり, その素子温度はインバータの負荷率, 使用環境温度, 運転頻度に左右される（大野，2006）。 パワーモジュールのベースプレートには，素子の熱を効率 良く放熱するために高熱伝導材が使用されており，それらの材料は線膨張率が比較的大きい（例えば銅で 17 


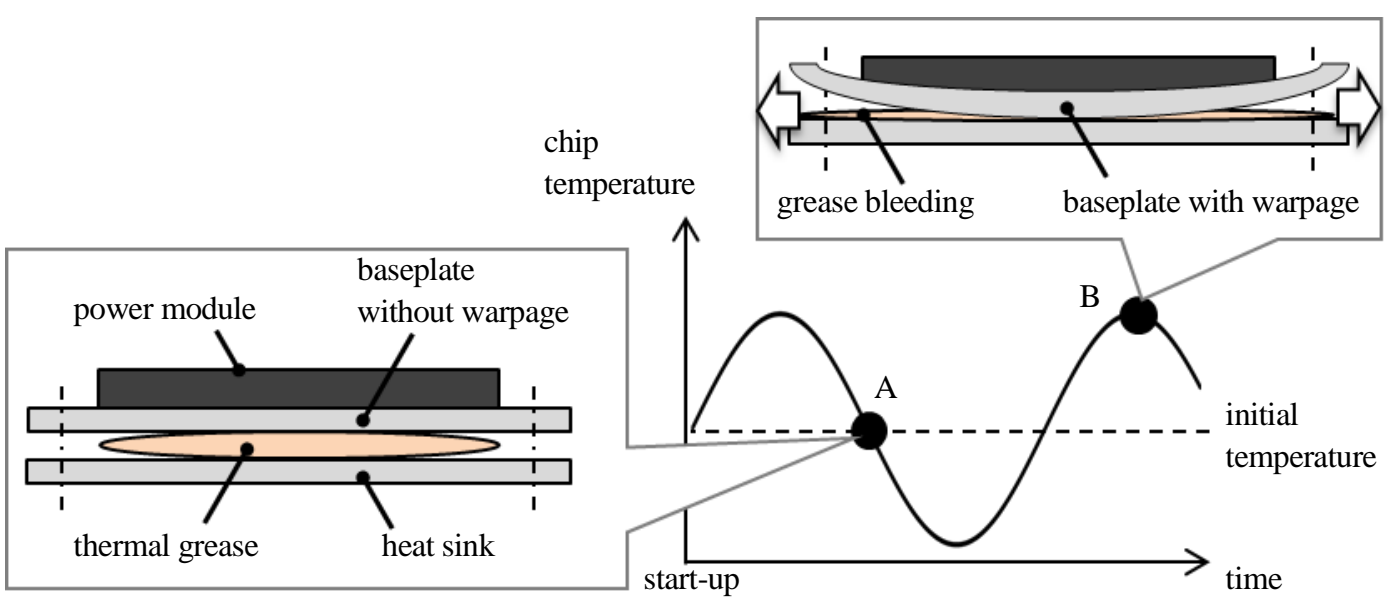

Fig. 2 Baseplate warpage in power module during thermal cycling.

$\mathrm{ppm} / \mathrm{K}$ ，アルミで $23 \mathrm{ppm} / \mathrm{K})$. ベースプレートは，線膨張率の小さい DCB 基板（例えばアルミナで $7 \mathrm{ppm} / \mathrm{K} ）$ と 接合されるため, ベースプレートと DCB 基板との間には線膨張率差が発生する. この線膨張率差は，パワーモ ジュール稼動時にベースプレートの反り変形を引き起こす，一方，ヒートシンクには，ベースプレートと同じく 銅やアルミなどが使用されるが，板厚が大きく，低線膨張率材料と接合されていないことから，反り変形を無視 できる.ここで，パワーモジュール稼働時における素子温度履歴とグリースの状態について概略を図 2 に示す. 素子が図中の温度サイクル下にある場合，時刻 A の温度上昇がない時にはベースプレートに反り変形が生じず， 時刻 B の温度上昇時にはベースプレートの反り変形が生じる. 時刻 B で反ったベースプレートはグリースを圧縮 し，外側へ押し出す。このような反り変形が繰り返し発生することによって，押し出されたグリースが元の状態 に戻らない場合がある，以上のことから，本研究では，グリースの性質とパワーモジュールの稼働条件を想定し た影響因子に着目し，(1)グリースの硬化性，(2)ベースプレートの反り変形量，(3反り変形が生じる周期の 3 因子 について検証する.

\section{$2 \cdot 2$ テストセクションと可視化手法}

前述したベースプレートの反り変形については，機械的な負荷による反り変形の模擬がこれまでに検討されて きた（藤本，上貝，2010）。しかし，荷重変形と線膨張率差による熱変形では，ひずみの発生形態が異なることか らベースプレートの反り形状が異なる. 反り形状の差異を確認するために，図 3 のような DCB 基板（ヤング率 $250 \mathrm{GPa}$ ，線膨張率 $7 \mathrm{ppm} / \mathrm{K}$ ）がベースプレート（ヤング率 $120 \mathrm{GPa}$ ，線膨張率 $17 \mathrm{ppm} / \mathrm{K}$ ）にはんだ（ヤング率 40

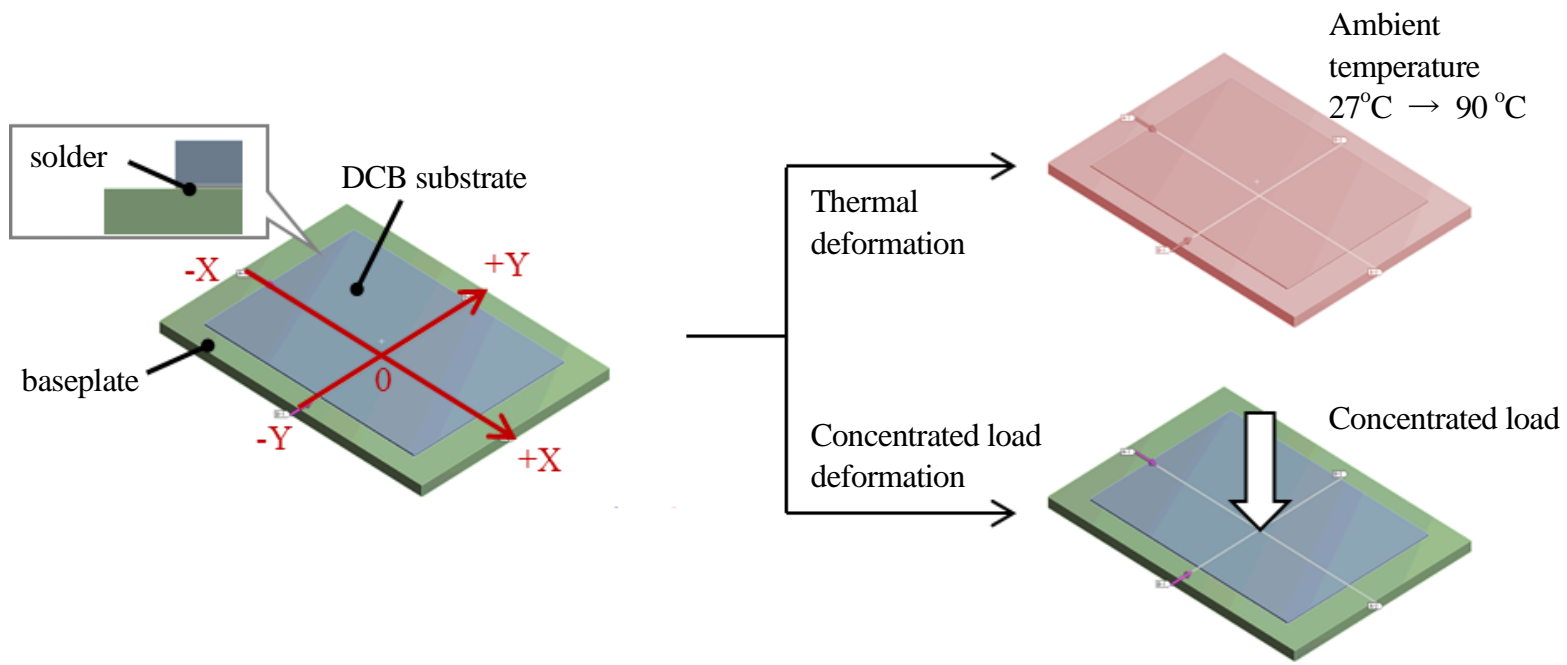

Fig. 3 Comparison between thermal and concentrated load deformation. 
$\mathrm{GPa}$ ，線膨張率 $20 \mathrm{ppm} / \mathrm{K}$ ）で接合された 3 層構造を例に挙げて, 熱変形と荷重変形による反り量を比較した. 各 層の寸法形状は, DCB 基板が $112 \mathrm{~mm}$ x $80 \mathrm{~mm}$ の厚さ $1 \mathrm{~mm}$ ，はんだが $112 \mathrm{~mm}$ x $80 \mathrm{~mm}$ の厚さ $0.1 \mathrm{mm，ベースプレ}$ 一トが $140 \mathrm{~mm}$ x $100 \mathrm{~mm}$ の厚さ $5 \mathrm{~mm}$ である. 有限要素法によって各変形量を構造解析し，構造解析の支持条件は ベースプレート角部 4 点の単純支持とした. 図 4 は, 変形なしの基準温度 $27^{\circ} \mathrm{C}$ 号環境温度 $90^{\circ} \mathrm{C}$ に昇した場合 の熱変形と, 両変形モードの最大変位が等しくなる集中荷重（1.42kN）における荷重変形について有限要素解析 した結果である．横軸に解析モデル上の X 軸あるいは Y 軸をとり，縦軸に DCB 基板側を正とするべースプレー トの変位をとっている. 解析結果によると, 両変形モードは同じ方向に反りを有するが, その形状は一致しない. 特に，Y軸方向の形状に差異が見られることから，温度サイクル下での反り変形を再現するには，熱変形を利用 したテストセクションが必要と考えられる.

そこで，ポンプアウト現象を定量的に評価するために， ベースプレートの反り変形の模擬と，接続部へ充填し たグリースの形状可視化を試みた，そのために，非破壊評価を可能とする超音波可視化テストセクションを製作 した，テストセクションの断面図と写真を図 5 に示寸，テストセクションには，ベースプレートの反り変形を模 擬するためにバイメタルプレートを適用した．ヒートシンクのベース面に相当する箇所にはアルミ材を使用し， 曲げ剛性を高める目的で板厚 $10 \mathrm{~mm}$ とした. グリースは, ステンシルマスクを用いて直径 $\phi 11.3 \mathrm{~mm}$, 厚さ $0.3 \mathrm{~mm}$ の円柱状にアルミプレート側へ塗布された後に, バイメタルプレートとアルミプレートとの間に据え込まれたス

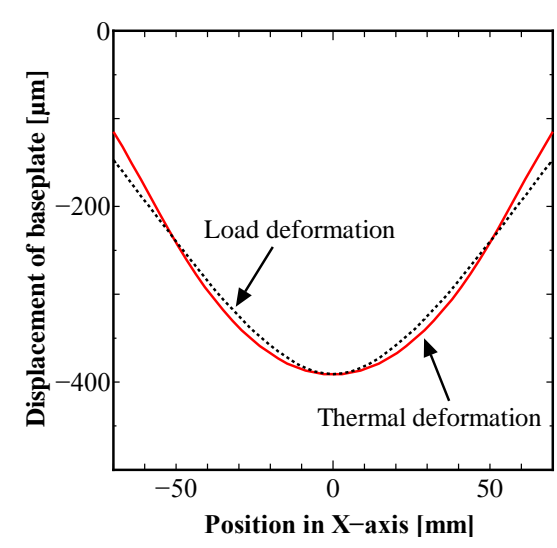

(a) X-direction.

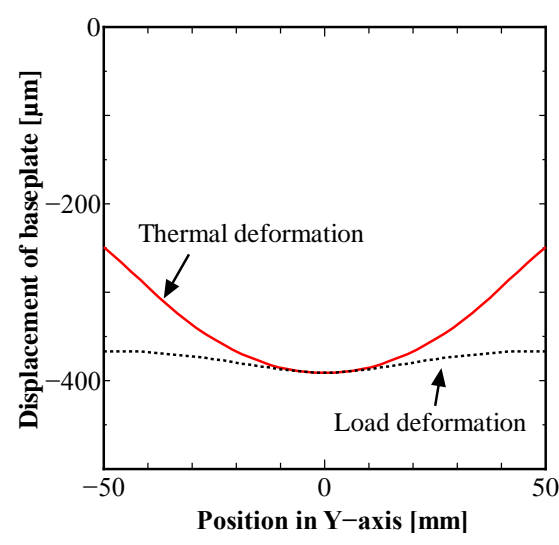

(b) Y-direction.

Fig. 4 Displacement of baseplate in case of thermal and concentrated load deformation.

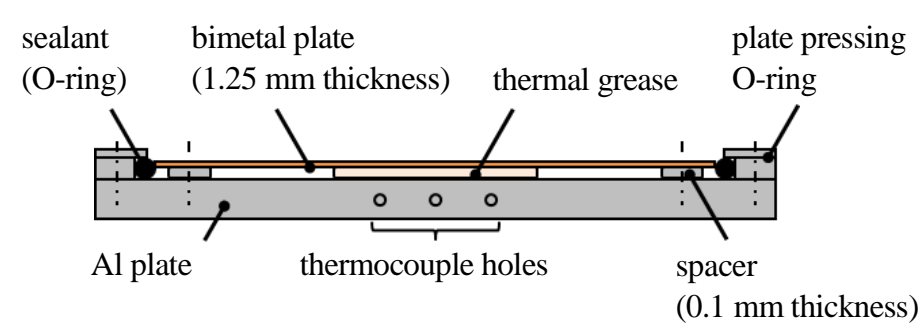

(a) Cross-section view.

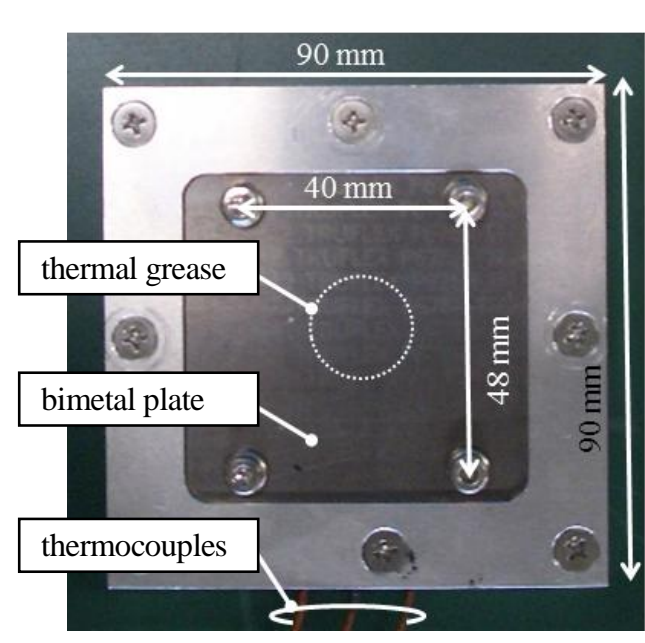

(b) Top view.

Fig. 5 Schematic of test section. 
ペーサにて厚さ $0.1 \mathrm{~mm}$ に調整される. 使用するバイメタルプレートの概略を図 6 に示す．バイメタルプレート は，高線膨張率を有する $70 \% \mathrm{Mn}-\mathrm{Cu}-\mathrm{Ni}$ 合金の板 $(30 \mathrm{ppm} / \mathrm{K})$ と，低線膨張率を有する $36 \% \mathrm{Ni}-\mathrm{Fe}$ 合金 $(1.1 \mathrm{ppm} / \mathrm{K})$ の板が接合されたものである. バイメタルプレートの温度が変化すると, 線膨張率差に起因して反り変形が生じ る. バイメタルプレートの仕様は, 線膨張率に相当する湾曲係数 $20.5 \mathrm{ppm} / \mathrm{K}$, 外形寸法は $62 \mathrm{~mm}$ x $59 \mathrm{~mm}$ の厚さ $1.25 \mathrm{~mm}$ である. ただし，バイメタルプレートは 4 本のボルトで固定され，図 5 に示寸ようにボルト軸間距離は $48 \mathrm{~mm}$ または $40 \mathrm{~mm}$ である. バイメタルプレートの支持条件としては 4 点の単純支持に相当する. 図 7 は, 本試 験に用いる 2 種類のグリースをテストセクションに塗布した状態で, 環境温度 $25{ }^{\circ} \mathrm{C}$ から温度上昇にともなう 中央部の反り量を実測し, 実測值を平均化した結果である. 実測の結果, 各グリースの実測值の差は $10 \mu \mathrm{m} 以 下$ であった。実測結果は, バイメタルプレートの反り量と温度上昇との間に比例関係が存在し, 温調によってバイ メタルプレートの反り量調整が可能であることを示している．超音波可視化の際には，テストセクションを水中 に沈める方式を採用し，O リングを用いたシール設計を施した．プローブ周波数は $25 \mathrm{MHz}$ (最小分解能 $7 \mu \mathrm{m})$ で画像を取得した，テストセクションは，重力によるグリースのたれ落ちを避けるために水平置きされる.

本手法では, テストセクションの温度サイクル試験後に, 規定サイクル回数でのグリースの形状計測を実施し た．影響因子(1)グリースの硬化性，(2)ベースプレートの反り変形量，(3)反り変形が生じる周期について感度を分 析できるように, 2 水準のグリースタイプ, 反り量, 温度サイクルの周波数を表 2 の通りに設定し, 表 3 に示す 直交表にしたがって検証した. 本研究では非硬化型および湿気硬化型のグリースを使用し, 塗布後に 24 時間静置 してから温度サイクル試験へ投入した，温度サイクル試験については，常温 $25{ }^{\circ} \mathrm{C}$ 基準に環境温度を高温側に 変化させ, 試験条件の反り量となるように温度差 $14 \mathrm{~K}$ と $28 \mathrm{~K}$ を設定した. その際，テストセクション全体が設 定温度となるように, 定常状態で 5 10 分間保持した. また，バイメタルプレートをステンレスプレート（外形 寸法 $62 \mathrm{~mm}$ x $59 \mathrm{~mm}$ の厚さ $1.25 \mathrm{~mm}$ ）に変更したサンプルについて, 反り変形の有無による影響も水準 $\mathrm{A}$ の条件 下で確認することとした.

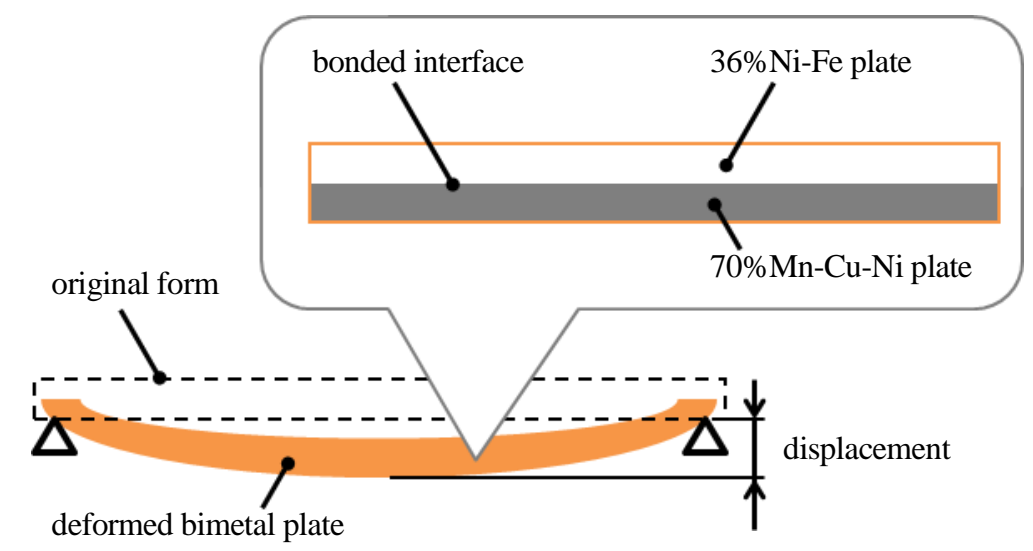

Fig. 6 Schematic of bimetal plate.

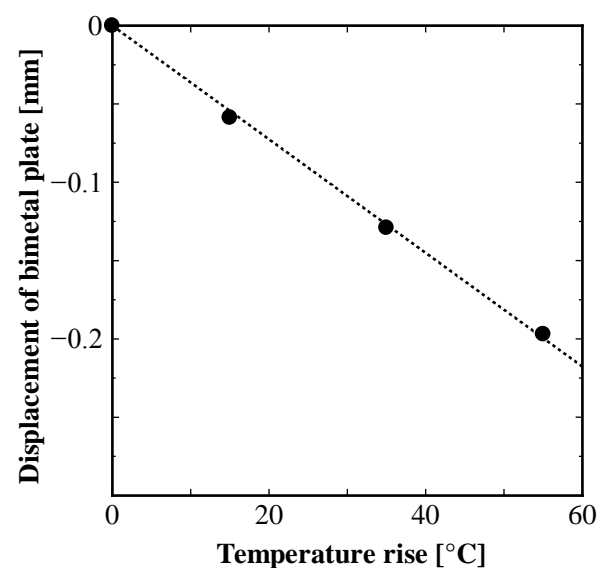

Fig. 7 Relationship between warpage of bimetal plate and temperature rise. 
Table 2 Correlated factors with grease pump-out.

\begin{tabular}{|c|c|c|c|}
\hline Item & $\begin{array}{l}\text { Factor 1: } \\
\text { thermal grease type }\end{array}$ & $\begin{array}{l}\text { Factor 2: } \\
\text { warpage }\end{array}$ & $\begin{array}{l}\text { Factor } 3 \text { : } \\
\text { thermal cycle frequency }\end{array}$ \\
\hline Level A & $\begin{array}{l}\text { Non-curing type } \\
\text { - viscosity } 50 \mathrm{~Pa} \cdot \mathrm{s}\end{array}$ & $\begin{array}{l}0.1 \mathrm{~mm} \\
\quad \text { - temperature rise of } 28 \mathrm{~K}\end{array}$ & $\begin{array}{l}667 \mu \mathrm{Hz} \\
-58 \text { cycles per day }\end{array}$ \\
\hline Level B & $\begin{array}{l}\text { Curing type } \\
\text { - cured with moisture } \\
\text { - viscosity } 80 \mathrm{~Pa} \cdot \mathrm{s} \text { before curing }\end{array}$ & $\begin{array}{l}0.05 \mathrm{~mm} \\
\quad \text { - temperature rise of } 14 \mathrm{~K}\end{array}$ & $\begin{array}{l}333 \mu \mathrm{Hz} \\
-29 \text { cycles per day }\end{array}$ \\
\hline
\end{tabular}

Table 3 Test condition.

\begin{tabular}{c|l|l|l}
\hline Sample No. & $\begin{array}{l}\text { Factor 1: } \\
\text { thermal grease type }\end{array}$ & $\begin{array}{l}\text { Factor 2: } \\
\text { warpage }\end{array}$ & $\begin{array}{l}\text { Factor 3: } \\
\text { thermal cycle frequency }\end{array}$ \\
\hline 1 & Level A & Level A & Level A \\
\hline 2 & Level A & Level B & Level B \\
\hline 3 & Level B & Level A & Level B \\
\hline 4 & Level B & Level B & Level A \\
\hline
\end{tabular}

\section{3. 検証結果および考察}

\section{$3 \cdot 1$ グリース形状の超音波可視化}

超音波可視化用のテストセクションに関して, 温度サイクル試験 100 回後に分解し，グリース形状を目視観察 した結果を表 4 に示す. ステンレスプレートで検証した結果と, バイメタルプレートを用いた試験条件 No.1 から No.4までの結果を示しており，超音波可視化画像については(a) 初期と(b) 100 回後を示している. 目視画像にお ける(c) アルミプレート側と(d) バイメタルプレート側に付着したグリースは, 超音波可視化画像(b) 100 回後のグ リースに相当する.両画像でグリース形状が概ね一致しており, 本手法によって非破壊評価できることがわかる. 試験条件 No.1 と No.2 の超音波可視化画像(a) 初期から, 破線枠 p 内においてグリースが少ない部分を確認でき る。これは，粘度が低い非硬化型グリースであることに起因しており，1 3 ${ }^{\circ} \mathrm{C}$ 程度の環境温度変化による反り変 形によって引き起こされる. 試験条件No.1 と No.2 については, 超音波可視化画像(a) 初期と(b) 100 回後を比較 すると，グリースの内部に多数のボイド（隙間）ができており，破線枠 $\mathrm{q}$ 内を比べればボイド部分にグリースが 残らないことを確認できる.これらのボイドは,バイメタルプレートの反り変形によって形成されたものであり， 反り変形に追従したグリースが元の形状に戻らない場合があることを意味する．ステンレスプレートのサンプル では反り変形が生じないため, 100 回後においてもグリース形状に変化が見られない. 試験条件 No.3 と No.4 で は反り変形が生じるのに対し，グリース形状に変化が見られない. これには硬化型グリースであることが影響し ていると考えられる. しかし, 試験条件 No.3 では破線枠 $\mathrm{r}$ 内に多くのクラックが生じており, 試験条件 No.4よ りも反り量が大きいことが原因と考えられる. 
Table 4 Comparison of grease form between ultrasonic image and real form.

\begin{tabular}{|c|c|c|c|c|}
\hline $\begin{array}{l}\text { Sample } \\
\text { No. }\end{array}$ & $\begin{array}{l}\text { (a) Ultrasonic image } \\
\text { (initial) }\end{array}$ & $\begin{array}{l}\text { (b) Ultrasonic image } \\
\text { (100 cycles) }\end{array}$ & $\begin{array}{l}\text { (c) Real form } \\
\text { (Al plate side) }\end{array}$ & $\begin{array}{c}\text { (d) Real form } \\
\text { (bimetal plate side) }\end{array}$ \\
\hline $\begin{array}{c}\text { SUS } \\
\text { plate } \\
\text { sample }\end{array}$ & grease & & & $\nabla$ \\
\hline 1 & & & & \\
\hline 2 & $\nabla$ & $\bar{\nabla}$ & & \\
\hline 3 & $\nabla$ & $\bar{\nabla}$ & & \\
\hline 4 & $\nabla$ & & & \\
\hline & $\boldsymbol{~}$ & 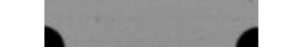 & & \\
\hline
\end{tabular}

以上のことから，繰り返し圧縮されたグリースにボイドが発生することが示唆された．接続部の熱抵抗増加を 引き起こすポンプアウト現象は，グリース内部でのボイド発生を特徽とする．試験条件 No.1 と No.2 においてボ イド発生が観察されたため，本研究のテストセクションがポンプアウト現象を再現できることを確認できた。一 方，テストセクション内部のグリースを可視化した結果，破線枠 $\mathrm{p}$ 内に $\mathrm{x}$ 方向の筋が発生していることと，超音 波可視化画像(a) 初期に対して(b) 100 回後のグリース形状が y 方向へ伸びていることを確認した. これは，本実 験で使用したバイメタルプレートが圧延接合品であったことが原因であると推察する. 使用したバイメタルプレ 一トの圧延時ロール方向は，表 4 の画像における $\mathrm{x}$ 方向に平行であった．圧延接合品はロール方向に直交する方 向（y 方向）の曲げに弱くなるため，直交する方向のひずみが比較的大きくなり，このひずみがグリースの形状 に強く影響したと考えられる. 図4 からわかるように，熱変形においては面内等方性のひずみが生じるべきであ り，実機のポンプアウト現象を再現するためには面内異方性を排除する必要がある. 本手法における対策として は，バイメタルプレートの基材からの板取方向を変えることが挙げられ，対策の検証は今後の課題である.

ここで，超音波可視化画像データを二值化処理し，グリース面積の定量的評価を試みた．温度サイクルにとも なうグリースの広がりは, グリースが圧縮されて薄くなることを意味する. 本研究ではグリースの塗布体積 ( $\mathrm{mm}$, 高さ $0.3 \mathrm{~mm}$ の円柱形状）の管理に加えて, グリースの厚さがスペーサ厚さ $0.1 \mathrm{~mm}$ に等しいと仮定するこ 


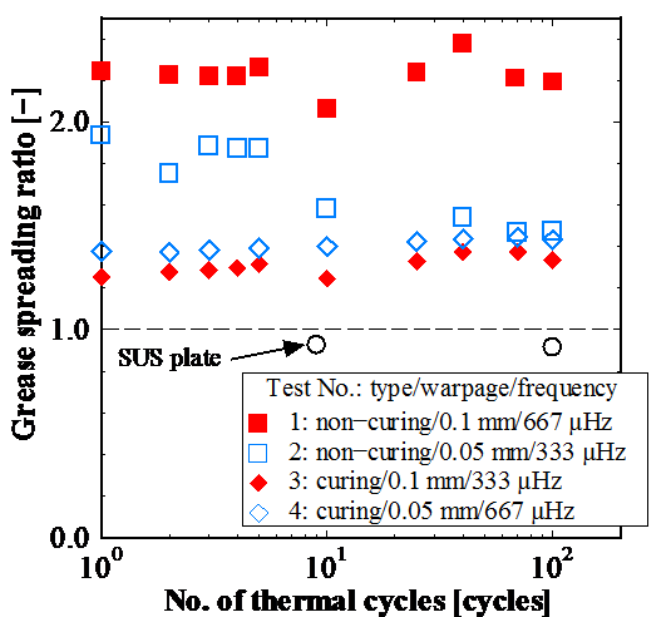

Fig. 8 Grease spreading ratio under thermal cycling.

とによって，広がりなしのグリース面積（約 $300 \mathrm{~mm}^{2}$ ）を概算した．図 8 に，温度サイクル数に対する，グリー ス広がり率（広がりなしのグリース面積と超音波可視化画像から得られるグリース面積との比）を示す．横軸に 温度サイクル数 (サイクル回数 1 回後から 100 回後まで), 縦軸にグリース広がり率をとっている. テストセクシ ヨン組み立て直後のグリース広がり率は, 試験条件 No.1 が 2.4, 試験条件 No.2 が 1.9, 試験条件 No.3 が 1.2, 試 験条件 No.4 が 1.4，ステンレスプレートのサンプルでは 0.92 であった. ステンレスサンプルについても図中にプ ロットしており，ステンレスプレートのサンプルではほとんどグリースが広がっていないことを確認できる。一 方，バイメタルプレートのサンプルについてはグリースの広がりを確認でき, 特に試験条件 No.1 と No.2 のグリ 一ス広がりは温度サイクル初期から大きい. 試験条件 No.2 は, 温度サイクル数の増加にともない減少するが，こ れはグリース内部に多数のボイドが発生したことによる．試験条件 No. 3 と No.4に関しては，グリースが徐々に 広がる傾向にある。

\section{$3 \cdot 2$ グリースの有効伝熱面積}

グリースが放熱に寄与する有効伝熱面積を評価するために，超音波可視化によって得られた形状データを利用 する. 有効伝熱面積の評価方法について，グリース形状の概略を示した図 9 を用いて説明する．発熱体である素 子を搭載したパワーモジュールの放熱において, グリース有無の影響が最も大きい箇所は素子直下である (Chiu et al., 1997)．素子直下でグリースがポンプアウトすると，空隙が形成されて接触熱抵抗の増大が顕著となり，素子 の温度上昇が大きくなってしまう.したがって, 素子からの伝熱経路を考慮して有効伝熱面積を求めることとし,

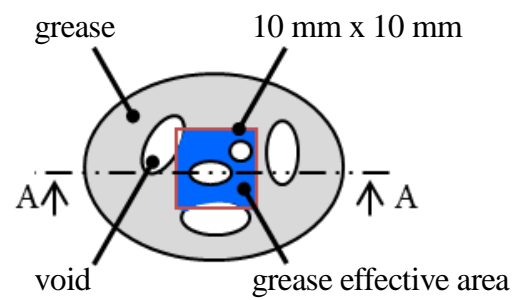

(a) Ultrasonic imaging data.

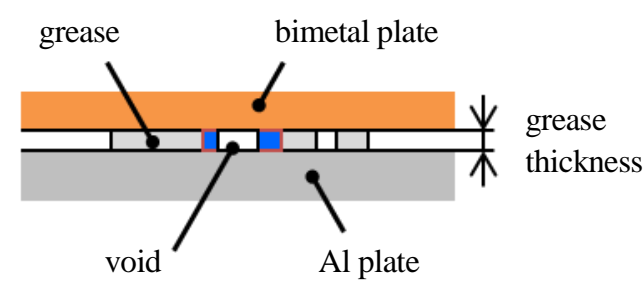

(b) A-A cross-section view.

Fig. 9 Calculation of effective grease area from ultrasonic images. 
初期可視化画像におけるグリース中央に示寸枠を面積評価部分と定義した．面積評価部分の大きさは素子を想定 して $10 \mathrm{~mm}$ x $10 \mathrm{~mm}$ とし，グリースの厚さと熱伝導率は一定であると仮定した.

温度サイクル数に対するグリース有効伝熱面積の履歴を図 10 に示す. 横軸に温度サイクル数, 縦軸にグリース 有効伝熱面積をとっている. 図から, 試験条件 No.1 と No.2 のグリースについては, 温度サイクル数の増加につ れて有効伝熱面積が大きく変化することがわかる．これは，バイメタルプレートの熱変形によって面積評価部分 のグリースが変動することを示している. 試験条件 No.1 においては, 有効伝熱面積が単調増加傾向にあり, グリ 一スが熱変形によって面積評価部分へ引き戻される作用を確認できる.この場合, 有効伝熱面積が増加するため, グリース層の熱抵抗が減少すると考えられる.一方, 試験条件 No.2では有効伝熱面積の増減が繰り返されている. 温度サイクル数 1 回から 100 回までの面積評価部分のグリース厚さと熱伝導率がほぼ一定であれば, 厚さ方向の 定常熱抵抗は有効伝熱面積によって決まる．面積評価部分のグリース厚さと熱伝導率が一定である場合の定常熱 抵抗を概算すると, 図中 A のサイクル数における定常熱抵抗は, 温度サイクル数 1 回の時点から $11 \%$ 大きくなる. すなわち, 温度サイクルにともなってグリース層の熱抵抗が増加することを想定して熱設計する必要がある. ス テンレスプレートのサンプルと試験条件 No.3 と No.4 については, 有効伝熱面積が一定となっており, 試験条件 No.3 と No.4 におけるバイメタルプレートの熱変形の影響は小さい. 低粘度のグリースを用いた試験条件 No.1 と No.2 に比べると, 硬化型のグリースを用いた試験条件 No.3 と No.4では熱変形によるグリースの変動が小さいこ とから, グリースの粘度増加がポンプアウト現象に対して有効であることを確認できる．また，面積評価部分の グリースが変動しなければ有効伝熱面積を維持できるため, 素子直下の初期接触熱抵抗を見積もるだけで熱設計 に反映できる見込みが得られた。

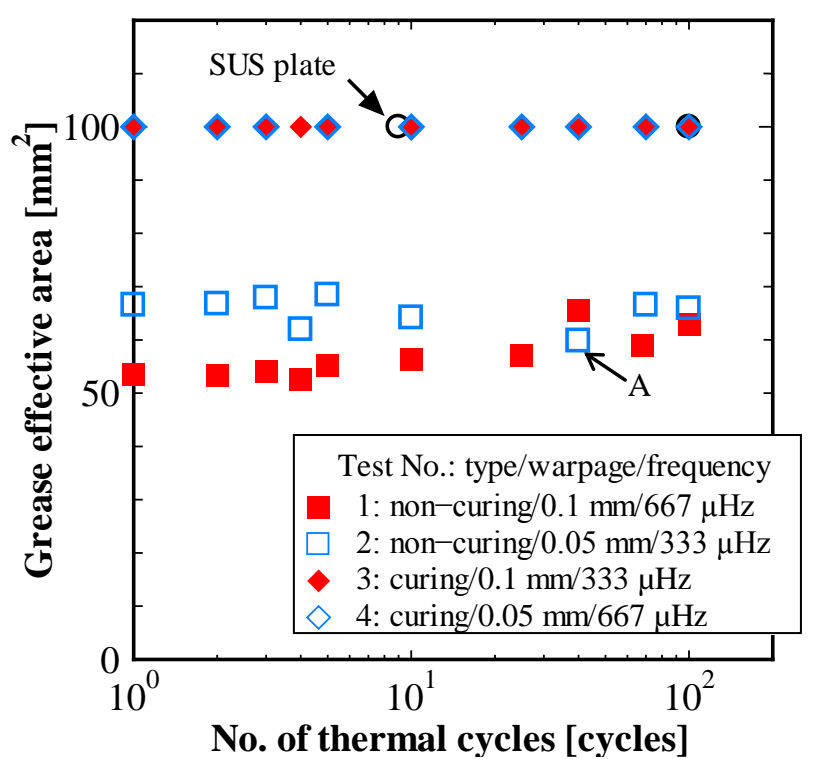

Fig. 10 Grease effective area under thermal cycling. 


\section{$3 \cdot 3$ グリースの面積比と影響因子の感度分析}

各試験条件の結果を分析するために, 前節までに求めたグリースの全体面積に対する有効伝熱面積の比（グリ 一ス面積比）を算出した．グリース面積比が大きいと，有効伝熱面積が大きいこと，あるいはグリースの広がり が小さいことを意味する. 温度サイクル数に対するグリース面積比の履歴を図 11 に示寸. 横軸に温度サイクル数, 縦軸にグリース面積比をとり，各プロットをべき乗関数でフィッティングした結果を鎖線で示すが，温度サイク ルにともなって試験条件 No.1 と No.2 では増加傾向, No.3 と No.4 では減少傾向となることを確認できる. 温度 サイクル 100 回でのグリース面積比を用いて各影響因子について感度分析した結果が図 12 である.横軸に影響因 子，縦軸には因子ごとに同水準で平均化したグリース面積比をとった。感度分析の結果，ポンプアウト現象に対 寸る影響因子(1)グリースの硬化性，(2)ベースプレートの反り量，(3)反り変形が生じる周期の 3 因子の中で，影響 因子(1)の感度が高いことがわかり, 影響因子(2)と(3)についてはほぼ同程度の感度であった.

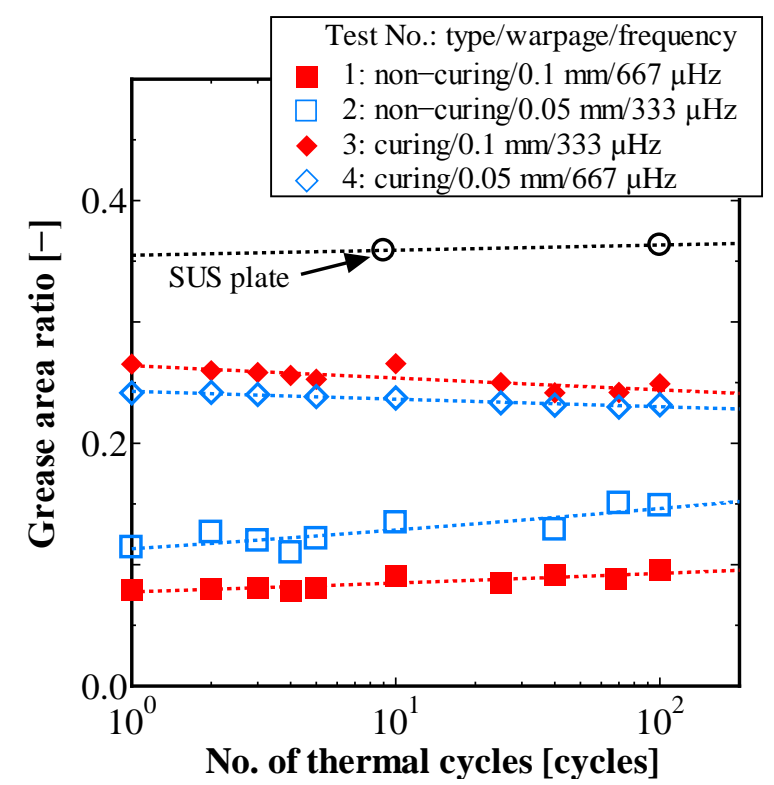

Fig. 11 Grease area ratio under thermal cycling.

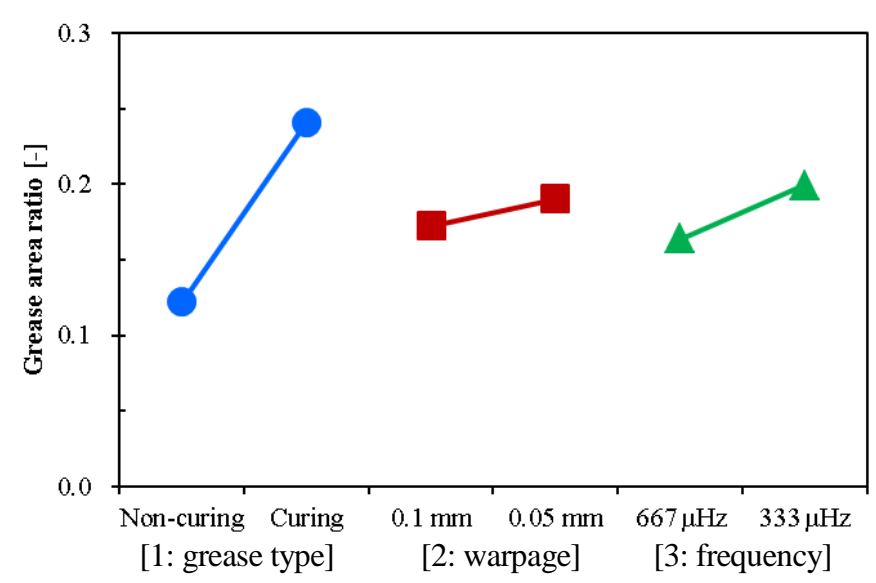

Fig. 12 Sensitivity analysis results. Grease type: Non-curing \& curing, Baseplate warpage: $0.1 \& 0.05$ mm, Thermal cycle frequency: $667 \& 333 \mu \mathrm{Hz}$. 


\section{4. 結 言}

グリースのポンプアウト現象の試験方法確立，ならびに現象発生のメカニズム解明につなげることを目的とし て，パワーモジュールの熱変形を模擬した装置で現象を再現し，非破壊評価した結果，以下の結論を得た。

（1）超音波可視化によってグリース形状を計測し，ポンプアウト現象を再現できることを確認した.

（2）温度サイクルにともなう繰り返し圧縮によって, 非硬化型グリース内部においてボイドが発生するのに 対し，硬化型グリースでは徐々に広がると同時にクラックが生じる.

（3）ベースプレートとヒートシンクとの接続部に硬化型グリースを適用する場合, 初期の接触熱抵抗を見積 もることによって接続部を熱設計できる見込みを得た.

（4）ポンプアウト現象に対する影響因子の感度分析から，グリース硬化性の感度が高く，ベースプレートの 反り量と温度サイクル周波数の感度は同程度であることを示した.

\section{文献}

Chiu, C., Solbrekken, G. L. and Chung, Y. D., Thermal modeling of grease-type interface material in PPGA application, Proceedings of the 13rd Semiconductor Thermal Measurement and Management Symposium (SEMI-THERM 1997) (1997), pp.57-63.

Chiu, C., Solbrekken, G. L. and Young, T. M., Thermal modeling and experimental validation of thermal interface performance between non-flat surfaces, Proceedings of the 7th Intersociety Conference on Thermal and Thermomechanical Phenomena in Electronic Systems (ITHERM 2000) (2000), pp.55-62.

Chiu, C., Chandran, B., Mello, M. and Kelley, K., An accelerated reliability test method to predict thermal grease pump-out in flip-chip applications, Proceedings of the 51st Electronic Components and Technology Conference (ECTC 2001) (2001), pp.91-97.

藤本慶久, 上貝康己, 半導体用伝熱グリースのポンピングアウト現象の定量評価, 日本機械学会 2010 年度年次大 会講演論文集 $(2010)$, pp.269-270.

小西祐一郎, 堀内敬介, 西原淳夫, 熱サイクルに伴うグリースポンプアウトの可視化試験方法, 第 52 回日本伝熱 シンポジウム講演論文集(CD-ROM) (2015), E312.

Linderman, R. J., Brunschwiler, T., Kloter, U., Toy, H. and Michel, B., Hierarchical nested surface channels for reduced particle stacking and low-resistance thermal interfaces, Proceedings of the 23rd Semiconductor Thermal Measurement and Management Symposium (SEMI-THERM 2007) (2007), pp.87-94.

Lutz, J., Schlangenotto, H., Scheuermann, U. and De Doncker, R., Semiconductor Power Devices, Springer (2011), pp.353-358.

大野榮一, パワーエレクトロニクス入門, オーム社 (2006), p.75.

Ramaswamy, C., Shinde, S., Pompeo, F., Sablinski, W. and Bradley, S., Phase change materials as a viable thermal interface material for high-power electronic applications, Proceedings of the 9th Intersociety Conference on Thermal and Thermomechanical Phenomena in Electronic Systems (ITHERM 2004) (2004), pp.687-691.

日本機械学会編, 伝熱工学資料 (2013), pp.281-290.

\section{References}

Chiu, C., Solbrekken, G. L. and Chung, Y. D., Thermal modeling of grease-type interface material in PPGA application, Proceedings of the 13rd Semiconductor Thermal Measurement and Management Symposium (SEMI-THERM 1997) (1997), pp.57-63.

Chiu, C., Solbrekken, G. L. and Young, T. M., Thermal modeling and experimental validation of thermal interface performance between non-flat surfaces, Proceedings of the 7th Intersociety Conference on Thermal and Thermomechanical Phenomena in Electronic Systems (ITHERM 2000) (2000), pp.55-62.

Chiu, C., Chandran, B., Mello, M. and Kelley, K., An accelerated reliability test method to predict thermal grease pump-out in flip-chip applications, Proceedings of the 51st Electronic Components and Technology Conference (ECTC 2001) 
(2001), pp.91-97.

Fujimoto, Y. and Uegai, Y., Evaluation of pumping out phenomenon of thermal grease for semiconductor, Proceedings of the 2010 JSME Annual Meeting (2010), pp.269-270 (in Japanese).

Konishi, Y., Horiuchi, K. and Nishihara, A., Visualization test method to evaluate thermal grease pump-out during thermal cycling, Proceedings of the 52st National Heat Transfer Symposium of Japan (CD-ROM) (2015), E312 (in Japanese).

Linderman, R. J., Brunschwiler, T., Kloter, U., Toy, H. and Michel, B., Hierarchical nested surface channels for reduced particle stacking and low-resistance thermal interfaces, Proceedings of the 23rd Semiconductor Thermal Measurement and Management Symposium (SEMI-THERM 2007) (2007), pp.87-94.

Lutz, J., Schlangenotto, H., Scheuermann, U. and De Doncker, R., Semiconductor Power Devices, Springer (2011), pp.353-358.

Ohno, E., Introductory power electronics, Ohmsha (2006), p.75 (in Japanese).

Ramaswamy, C., Shinde, S., Pompeo, F., Sablinski, W. and Bradley, S., Phase change materials as a viable thermal interface material for high-power electronic applications, Proceedings of the 9th Intersociety Conference on Thermal and Thermomechanical Phenomena in Electronic Systems (ITHERM 2004) (2004), pp.687-691.

The Japan Society of Mechanical Engineers ed., JSME data book: heat transfer 5th edition (2013), pp.281-290 (in Japanese). 